\title{
Quarterly Technical Progress Report - West Hackberry Tertiary Project
}

\author{
Quarterly Report \\ April 1 - June 30, 1998 \\ By: \\ Travis Gillham;Demetrios Yannimaras
}

Work Performed Under Contract No.: DE-FC22-93BC14963

\author{
For \\ U.S. Department of Energy \\ Office of Fossil Energy \\ Federal Energy Technology Center \\ P.O. Box 880 \\ Morgantown, West Virginia 26507-0880 \\ By \\ Amoco Energy Group North America \\ 150 West Warrenville Road \\ Naperville, Illinois 60566
}




\section{Disclaimer}

This report was prepared as an account of work sponsored by an agency of the United States Government. Neither the United States Government nor any agency thereof, nor any of their employees, makes any warranty, express or implied, or assumes any legal liability or responsibility for the accuracy, completeness, or usefulness of any information, apparatus, product, or process disclosed, or represents that its use would not infringe privately owned rights. Reference herein to any specific commercial product, process, or service by trade

name, trademark, manufacturer, or otherwise does not necessarily constitute or imply its endorsement, recommendation, or favoring by the United States Government or any agency thereof. The views and opinions of authors expressed herein do not necessarily state or reflect those of the United States Government or any agency thereof. 


\title{
QUARTERLY TECHNICAL PROGRESS REPORT 4/1/98-6/30/98
}

\author{
WEST HACKBERRY TERTIARY PROJECT
}

Cooperative Agreement No. DE-FC22-93BC14963--20

\section{Amoco Production Company}

Date of Report: 7/14/98

Award Date: 9/3/93

Anticipated Completion Date: 3/31/99 (Budget Period 1)

Government Award: \$6,017,500 (Budget Period 1)

Program Manager: Travis Gillham

Principal Investigators: Travis Gillham, Demetrios Yannimaras (research)

Technical Project Officer: Dan Ferguson

Reporting Period: 4/1/98-6/30/98 (19th Quarter of Budget Period 1) 


\begin{abstract}
The West Hackberry Tertiary Project is a field test of the concept that air injection can generate tertiary oil recovery through the Double Displacement Process. The Double Displacement Process is the gas displacement of a water invaded oil column for the purpose of recovering tertiary oil through gravity drainage. The novel aspect of this project is the use of air as the injection fluid. In Gulf Coast oil reservoirs with pronounced bed dip, reservoir performance has shown that gravity drainage recoveries average $80 \%$ to $90 \%$ of the original oil in place while water drive recoveries average $50 \%$ to $60 \%$ of the original oil in place. The target for tertiary oil recovery with the Double Displacement Process is the incremental oil between the $50 \%$ to $60 \%$ water drive recoveries and the $80 \%$ to $90 \%$ gravity drainage recoveries. The use of air injection in this process combines the benefits of air's low cost and universal accessibility with the potential for improved oil recovery resulting from spontaneous in situ combustion. If successful, this project will demonstrate that utilizing air injection in the Double Displacement Process will result in an economically viable tertiary process in many Gulf Coast oil reservoirs where other tertiary processes are presently uneconomic. The West Hackberry Tertiary Project receives matching funds from the United States Department of Energy (DOE) as part of the DOE's Class 1 Program for the development of advance recovery technologies in fluvial dominated deltaic reservoirs. In addition, the Petroleum Engineering Department at Louisiana State University (LSU) provides independent study and technology transfer.
\end{abstract}

\title{
Objectives
}

The goal of the West Hackberry Tertiary Project is to demonstrate the technical and economic feasibility of combining air injection with the Double Displacement Process for tertiary oil recovery. The concept is being field tested in low pressure (300 to 600 pounds per square inch (psi)) reservoirs on the North Flank of the field and high pressure reservoirs (2500 to 3300 psi) on the West Flank of the field.

The low pressure reservoirs on the North Flank of the field are characterized by steep bed dips, large low pressure gas caps, slow water encroachment and thin oil rims. A thin oil rim on a steeply dipping structure occupies a small area. As water encroaches, a producing well will water out while upstructure wells will still reside in the gas cap. Finding an economic method to produce the oil rim represents a considerable challenge. Air injection in this situation can increase oil recovery by: 1)repressurizing the reservoir, 2)pushing the oil rim to downstructure producing wells and 3)effective use of the Double Displacement Process.

The high pressure reservoirs on the West Flank are under active water drive and all producing wells have watered out. Air injection in the high pressure reservoirs is expected to generate tertiary oil recovery through the Double Displacement Process. 


\section{$\underline{\text { Summary of Technical Progress }}$}

Through June of 1998, air injection in the three low pressure reservoirs on the North Flank had increased oil production by 100,000 barrels over the expected decline. Air injection is currently ongoing in only two of the four project reservoirs due to iron oxide plugging in the air injectors. As shown on the production plot on Figure 1, the combined June production rate for the three low pressure reservoirs was 495 barrels of oil per day (BOPD) or 250 BOPD greater than the expected decline. In the high pressure West Flank reservoir, air injection has increased reservoir pressure by $500 \mathrm{psi}$ and a recent sidetrack is expected to generate the project's first oil production in a high pressure reservoir. The following is an update of the second quarter activities for each of the project reservoirs along with a review of the technology transfer events.

\section{$\underline{\text { Cam C (North Flank) }}$}

The injector for the North Flank Cam C reservoir is the SL 42 No. 155. When the SL 42 No. 155 became plugged with iron oxide and workover operations were unsuccessful in cleaning it out, the well was sidetracked. Air injection commenced in the sidetrack during March of this year. A combination of renewed air injection along with some production optimization has increased oil production in the North Flank Cam C by 220 BOPD over the decline. See Figure 2.

Four Cam $\mathrm{C}$ wells are producing at higher rates as a result of air injection. During the second quarter, the SL 42 No. 98 was sidetracked out of the gas cap into the oil rim to increase the number of producing wells to five. Workover operations to complete the SL 42 No. 98 as a producing well will begin in July or early August.

Although air injection is improving recovery, injection rates have been less than planned due to continued problems with iron oxide in the injection lines. At higher injection rates, the wellhead air filters have become plugged as often as twice a day. A team of field personnel and engineers is working to solve this problem.

\section{Bol 3 (North Flank)}

In December of 1997, the injector for the North Flank Bol 3 reservoir, the GLAC No. 245, became plugged with iron oxide and could not be cleaned out. While air injection had increased production in this reservoir, the lack of injection over the past six months has allowed production to decline. A production plot for the North Flank Bol 3 reservoir is included as Figure 3. Permits have been obtained to convert an alternate well, the GLAC No. 42 , to air injection. The conversion will take place when a workover rig becomes available. 


\section{Cam D (North Flank)}

In December of 1997, the North Flank Cam D became the largest low pressure reservoir to undergo air injection at West Hackberry. The North Flank Cam D has two producing wells. The CPSB No. 57 is the producer nearest to the injector and the only well of the two that has responded to air injection so far. As shown on Figure 4, the water cut $n$ the CPSB No. 57 had gradually increased over the past year while oil rates steadily declined. As a result of air injection, oil production in the CPSB No. 57 increased from 52 BOPD in May to 74 BOPD in June. Recent production tests of the CPSB No. 57 from late June to early July are showing that the water cut has leveled out and started to decrease. The decrease in water cut is the result of air injection expanding the gas cap and thereby pushing the oil rim downstructure.

When a rig becomes available, additional workovers are planned to complete two other wells in the Cam D reservoir. The CPSB No. 26 and the CPSB No. 55 had previously watered out in the Cam D. As air injection pushes the oil rim downstructure, the CPSB Nos. 26 and 55 should produce oil once again.

\section{Cam C (West Flank)}

Permits have been obtained to convert the GLD No. 45 to air injection to replace the GLD No. 51. The GLD No. 51 became plugged with iron oxide, was sidetracked and completed as a producing well in the Cam C-3. Initial tests from the GLD No. 51 were 14 BOPD, 120 BWPD and 700 MCFD (75\% nitrogen). The well will be placed on continuous production during July with the expectation that the oil cut will increase after the nitrogen gas cap has been blown down. The GLD No. 45 will be converted to air injection when a rig becomes available. Once air injection begins in the GLD No. 45, pulsed neutron logs will be run periodically in the GLD No. 51 to monitor the arrival of the Cam C-1 oil rim. When the Cam C-1 oil rim reaches the GLD No. 51, the Cam C-1 will be added to the completion interval.

\section{5)Technology Transfer Activities}

The SPE/DOE Eleventh Symposium on Improved Oil Recovery was held on April 19-22, 1998, in Tulsa, Oklahoma. A paper entitled "Low Cost IOR: An Update on the West Hackberry Air Injection Project" was presented at that time. The talk was well attended with a lively question and answer period followed the presentation. If ongoing efforts to increase production are successful, this will generate additional interest and thereby spur on another round of technology transfer activities. 


\section{Figures:}

1) Composite Production Plot for All Three Low Pressure North Flank Reservoirs

2) Composite Production Plot for the North Flank Cam C

3) Composite Production Plot for the North Flank Bol 3

4) Production Plot for the North Flank Cam D

\section{$\underline{\text { SI Metric Conversion Factors }}$}

bbl x 1.589873

$\mathrm{E}-01=$ cubic meters

cubic feet x 2.831685

$\mathrm{E}-\mathrm{02}=$ cubic meters

psi $\times 6.894757$

$$
\mathrm{E}+00=\mathrm{kPa}
$$



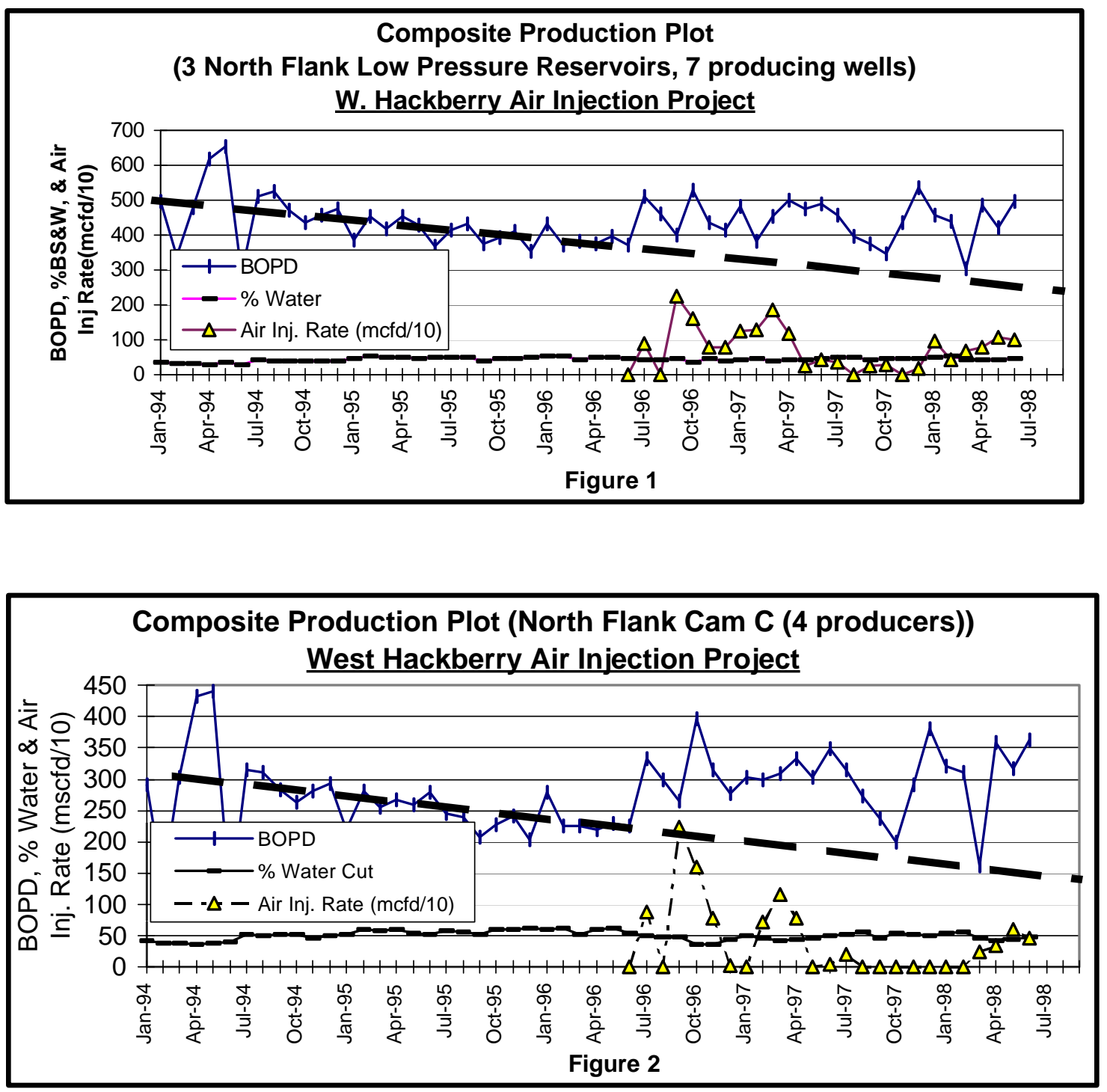

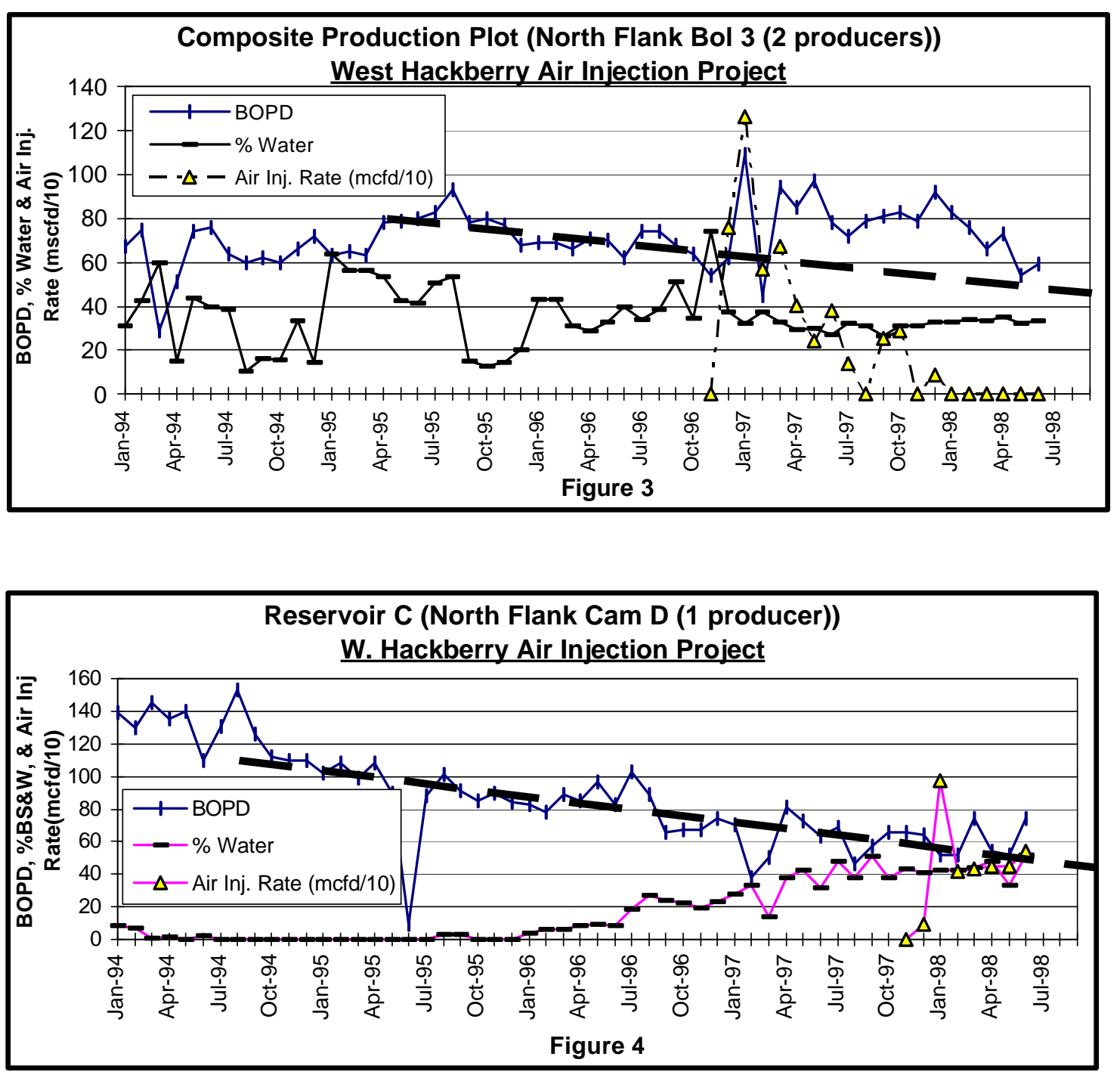